DOI: https://doi.org/10.47405/mjssh.v5i5.419

\begin{tabular}{|c|c|}
\hline - & Malaysian Journal of Social Sciences and Humanities (MJSSH) \\
\hline Malaysian Journal of & Volume 5, Issue 5, May 2020 \\
\hline (MJ. SSH) & e-ISSN : 2504-8562 \\
\hline & $\begin{array}{l}\text { Journal home page: } \\
\text { www.msocialsciences.com }\end{array}$ \\
\hline
\end{tabular}

\title{
Tahap Pengamalan Kemahiran Pemikiran Sejarah Melalui Penggunaan Sumber Digital Sejarah dalam Pendekatan Flipped Classroom
}

\author{
M. Kaviza ${ }^{1}$ \\ 1Pusat Pengajian Pendidikan dan Bahasa Moden, Universiti Utara Malaysia (UUM) \\ Correspondence: M. Kaviza (kavizakaviza@yahoo.com)
}

\begin{abstract}
Abstrak
Kajian berbentuk deskriptif ini bertujuan untuk mengenal pasti tahap pengamalan kemahiran pemikiran sejarah dan konstruknya iaitu kemahiran memahami kronologi, kemahiran meneroka bukti, kemahiran membuat interpretasi, kemahiran membuat imaginasi dan kemahiran membuat rasionalisasi melalui penggunaan sumber digital sejarah dalam pendekatan Flipped Classroom. Kajian ini melibatkan seramai 32 orang murid Tingkatan Satu melalui teknik persampelan berkelompok dijadikan sampel kajian ini. Soal selidik yang diadaptasi yang telah disahkan oleh pakar penilai dalam bidang pendidikan sejarah dan mempunyai nilai kebolehpercayaan yang baik dijadikan instrumen kajian ini. Data kajian ini telah dianalisis secara deskriptif dan inferensi iaitu ujian-t sampel tak bersandar dan ujian MANOVA melalui perisian IBM SPSS versi 24. Dapatan kajian ini menunjukkan bahawa tahap pengamalan kemahiran pemikiran sejarah dan kelima-lima konstruknya adalah sederhana. Selain itu, tahap pengamalan kemahiran pemikiran sejarah dan konstruknya juga berada pada tahap sederhana bagi murid lelaki dan perempuan walaupun hanya kemahiran memahami kronologi sahaja yang dilaporkan berada pada tahap tinggi bagi murid perempuan. Tambahan pula, dapatan kajian ini juga menunjukkan bahawa tidak terdapat perbezaan yang signifikan bagi min pengamalan kemahiran pemikiran sejarah dan kelima-lima konstruknya berdasarkan jantina. Implikasi kajian ini diharapkan dapat menjadi sumber rujukan kepada guru-guru sejarah dalam merancang inovasi dalam kaedah pengajaran dan pembelajaran sejarah sedia ada.
\end{abstract}

Kata kunci: pendekatan flipped classroom, sumber digital sejarah, kemahiran pemikiran sejarah

\section{The Level of the Practising of Historical Thinking Skills through Using Historical Digital Sources in Flipped Classroom Approach}

\begin{abstract}
The descriptive study aims to identify the level of the practising of historical thinking skills and its constructs, namely chronology, evidens exploration, interpretation, imagination and rationalization skills through using historical digital sources in Flipped Classroom Approach. This study involved 32 form one student through cluster sampling technique as a sample. The adapted questionnaires which are validated by experts and have good reliability are used as research instrument in this study. The data of this study were analyzed descriptively and inference, such as independent sampel t-test and MANOVA test using IBM SPSS version 24 software. The findings of this study indicated that the level of the practising of historical thinking skills and its construct at a moderate level. Beside that, the level of the practising of historical thinking skills and its construct also at a moderate level among boy and girl students, eventhough only choronology skills are reported at high level for girl students in this
\end{abstract}


DOI: https://doi.org/10.47405/mjssh.v5i5.419

study. In addition, the findings also showed that there is no significant difference in the mean of the practising of historical thinking skills and its construct based on gender. The implications of this study are expected to be a source of reference for history teachers in designing innovations in existing teaching and learning methods.

Keywords: flipped classroom approach, historical digital sources, historical thinking skills

\section{Pengenalan}

Adalah diakui bahawa sumber-sumber sejarah merupakan bahan-bahan yang digunakan untuk mengkaji sesuatu peristiwa sejarah pada masa lampau yang membolehkan murid dapat melibatkan diri secara aktif dalam proses interpretasi sejarah dalam proses pengajaran dan pembelajaran sejarah yang membolehkan murid dapat membina pengetahuan sejarah dan membandingkan tafsiran yang dibuat oleh ahli sejarah (Barton, 2018; Hazri Jamil, 2003; Haydn, Arthur \& Hunt, 2001). Perkembangan teknologi maklumat kini membolehkan murid dapat mengakses pelbagai sumber digital sejarah dengan lebih mudah seperti laporan, surat, dokumen, rekod, enskliopedia, majalah, buku teks dan sebagainya yang dapat meningkatkan proses pemikiran dan pemahaman murid (Library of Congress, 2018; Hendry, 2007). Sungguhpun begitu, pendekatan Flipped Classroom kini semakin dipratikkan dalam sistem pendidikan dalam menggalakkan proses pembelajaran berpusatkan murid dan strategi pembelajaran abad ke-21 (Leich, Zappe, Messner \& Litzinger, 2012; Tucker, 2012; Wilson, 2013). Perkembangan pendekatan ini adalah selaras untuk menyahut dasar pendidikan negara untuk melengkapkan murid dengan pelbagai pengetahuan dan kemahiran agar mereka dapat bersaing pada peringkat global (PPK, 2003, 2018). Pendekatan Flipped Classroom merupakan pendekatan pembelajaran yang menyediakan waktu pembelajaran di luas kelas untuk membaca bahan pembelajaran, manakala waktu di dalam kelas pula digunakan untuk tujuan penguasaan, pemahaman dan pembinaan pengetahuan berdasarkan bahan pembelajaran yang dibekalkan (Bergamann \& Sams, 2012; Hamdan, Knight, \& Arfstrom, 2013; Lage, Platt, Tregilia, 2000). Proses pembelajaran melalui pendekatan Flipped Classroom membolehkan murid-murid dapat meningkatkan penyertaan mereka semaksimumnya dalam proses pembelajaran di dalam kelas, di samping mereka juga dapat melibatkan diri dengan proses pemikiran aras tinggi (Mohamad Amin \& Ebrahim Panah, 2014; Rozinah Jamaludin \& Siti Zuraidah Md Osman, 2014; Strayer, 2012; Bergamann \& Sams, 2012).

Tidak dinafikan bahawa pendekatan Flipped Classroom dibuktikan memberikan impak positif dalam proses pembelajaran sejarah (Gaughan, 2014; Aidinopoulou \& Sampson 2017; Westermann, 2014), namun begitu terdapat satu keperluan untuk mengkaji pelaksanaan pendekatan tersebut dengan menggunakan sumber digital sejarah dalam membentuk pengamalan kemahiran pemikiran sejarah perlu dilakukan. Hal ini selaras dengan dapatan kajian-kajian lepas yang telah melaporkan bahawa tahap pengamalan kemahiran pemikiran sejarah dalam kalangan perlu dipertingkatkan secara efisien dalam proses pengajaran dan pembelajaran sejarah (Cowgill II \& Waring, 2017; Wineburg, 1991; Atkin, 2016; Rosy Talin, 2015). Sehubungan dengan itu, terdapat lima kemahiran pemikiran sejarah iaitu memahami kronologi, meneroka bukti, membuat interpretasi, membuat imaginasi dan membuat rasionalisasi yang perlu dipupuk dan diaplikasikan dalam kalangan murid bagi membolehkan mereka memahami ciri-ciri sejarah dan meningkatkan proses pemikiran kritis (PPK, 2018). Justeru, terdapat satu keperluan kepada pengkaji kajian ini untuk mengenal pasti tahap pengamalan kemahiran pemikiran sejarah dalam kalangan murid selaras dengan ledakan literasi maklumat dan teknologi. Maka, kajian ini adalah bertujuan untuk mengenal pasti tahap pengamalan kemahiran pemikiran sejarah melalui penggunaan sumber digital sejarah dalam pendekatan Flipped Classroom dalam kalangan murid.

\section{Objektif Kajian}

Objektif kajian ini ialah: 
i. Mengenal pasti tahap pengamalan kemahiran pemikiran sejarah dan kelima-lima konstruknya iaitu kemahiran memahami kronologi, kemahiran meneroka bukti, kemahiran membuat interpretasi, kemahiran membuat imaginasi dan kemahiran membuat rasionalisasi melalui penggunaan sumber digital sejarah dalam pendekatan Flipped Classroom

ii. Mengenal pasti tahap pengamalan kemahiran pemikiran sejarah dan kelima-lima konstruknya iaitu kemahiran memahami kronologi, kemahiran meneroka bukti, kemahiran membuat interpretasi, kemahiran membuat imaginasi dan kemahiran membuat rasionalisasi melalui penggunaan sumber digital sejarah dalam pendekatan Flipped Classroom bagi murid lelaki dan murid perempuan.

iii. Mengenal pasti sama ada terdapat perbezaan min pengamalan kemahiran pemikiran sejarah dan kelima-lima konstruknya iaitu kemahiran memahami kronologi, kemahiran meneroka bukti, kemahiran membuat interpretasi, kemahiran membuat imaginasi dan kemahiran membuat rasionalisasi melalui penggunaan sumber digital sejarah dalam pendekatan Flipped Classroom berdasarkan jantina.

\section{Soalan Kajian}

Soalan kajian ini ialah:

i. Apakah tahap pengamalan kemahiran pemikiran sejarah dan kelima-lima konstruknya iaitu kemahiran memahami kronologi, kemahiran meneroka bukti, kemahiran membuat interpretasi, kemahiran membuat imaginasi dan kemahiran membuat rasionalisasi melalui penggunaan sumber digital sejarah dalam pendekatan Flipped Classroom?

ii. Apakah tahap pengamalan kemahiran pemikiran sejarah dan kelima-lima konstruknya iaitu kemahiran memahami kronologi, kemahiran meneroka bukti, kemahiran membuat interpretasi, kemahiran membuat imaginasi dan kemahiran membuat rasionalisasi melalui penggunaan sumber digital sejarah dalam pendekatan Flipped Classroom bagi murid lelaki dan murid perempuan?

iii. Adakah terdapat perbezaan min pengamalan kemahiran pemikiran sejarah dan kelima-lima konstruknya iaitu kemahiran memahami kronologi, kemahiran meneroka bukti, kemahiran membuat interpretasi, kemahiran membuat imaginasi dan kemahiran membuat rasionalisasi melalui penggunaan sumber digital sejarah dalam pendekatan Flipped Classroom berdasarkan jantina?

\section{Hipotesis Kajian}

Bagi menjawab soalan kajian 3, maka hipotesis kajian berikut telah dibentuk untuk diuji pada aras kesignifikan $p=0.05$ iaitu:

$\mathrm{H}_{\mathrm{o} 1}$ : Tidak terdapat perbezaan yang signifikan bagi min pengamalan kemahiran pemikiran sejarah melalui penggunaan sumber digital sejarah dalam pendekatan Flipped Classroom berdasarkan jantina.

$\mathrm{H}_{02}$ : Tidak terdapat perbezaan yang signifikan bagi min pengamalan kemahiran memahami kronologi, kemahiran meneroka bukti, kemahiran membuat interpretasi, kemahiran membuat imaginasi dan kemahiran membuat rasionalisasi melalui penggunaan sumber digital sejarah dalam pendekatan Flipped Classroom berdasarkan jantina.

\section{Metod Kajian}

Kajian tinjauan berbentuk deskriptif ini melibatkan seramai 32 orang murid Tingkatan Satu dari sebuah sekolah menengah harian yang ditentukan berdasarkan teknik persampelan berkelompok. Instrumen 
kajian ini adalah soal selidik kemahiran pemikiran sejarah yang telah diadaptasi yang digunakan untuk mengukur tahap kecenderungan pengamalan kemahiran pemikiran sejarah dalam kalangan murid. Soal selidik tersebut telah menjalani proses kesahan kandungan oleh dua orang pakar penilai dalam bidang pendidikan sejarah serta mempunyai nilai kebolehpercayaan (Cronbach Alfa $=0.95$ ) yang baik dan diterima untuk tujuan kajian ini (Nunnally, 1978). Murid-murid menjalani proses pengajaran dan pembelajaran bagi topik Tamadun Awal Dunia. Data kajian ini dianalisis secara deskriptif dan inferensi iaitu ujian-t sampel tak bersandar dan ujian MANOVA melalui perisian IBM SPSS versi 24. Interpretasi tahap pengamalan kemahiran pemikiran sejarah dalam kajian ini adalah dilakukan berdasarkan tiga tahap yang diadaptasi daripada kajian Jamil Ahmad, (2002) seperti yang ditunjukkan pada Jadual 1.

Jadual 1: Interpretasi Tahap Pengamalan Kemahiran Pemikiran Sejarah

\begin{tabular}{cc}
\hline Skor Min & Tahap \\
\hline $1.00-2.33$ & Rendah \\
$2.34-3.66$ & Sederhana \\
$3.67-5.00$ & Tinggi \\
\hline
\end{tabular}

Sumber: Adaptasi daripada Jamil Ahmad, (2002)

\section{Dapatan Kajian}

\section{Tahap pengamalan kemahiran pemikiran sejarah melalui penggunaan sumber digital sejarah dalam pendekatan Flipped Classroom}

Berdasarkan Jadual 2, tahap pengamalan kemahiran pemikiran sejarah $(M=3.38, S D=0.71)$ adalah berada pada sederhana dalam kajian ini. Dari aspek konstruknya pula, tahap pengamalan kemahiran memahami kronologi $(M=3.55, S D=0.82)$, kemahiran meneroka bukti $(M=3.39, S D=0.95)$, kemahiran membuat interpretasi $(M=3.33, S D=0.83)$, kemahiran membuat imaginasi $(M=3.38, S D=0.73)$ dan kemahiran membuat rasionalisasi $(M=3.26, S D=0.74)$ adalah berada pada tahap sederhana dalam kajian ini. Sungguhpun begitu, tahap pengamalan kemahiran memahami kronologi adalah lebih tinggi berbanding dengan kemahiran meneroka bukti, kemahiran membuat interpretasi, kemahiran membuat imaginasi dan kemahiran membuat rasionalisasi. Justeru, dapat dirumuskan bahawa tahap pengamalan kemahiran pemikiran sejarah dan kelima-lima konstruknya iaitu kemahiran memahami kronologi, kemahiran meneroka bukti, kemahiran membuat interpretasi, kemahiran membuat imaginasi dan kemahiran membuat rasionalisasi melalui penggunaan sumber digital sejarah dalam pendekatan Flipped Classroom berada pada tahap sederhana dalam kajian ini.

Jadual 2: Skor Min Pengamalan Kemahiran Pemikiran Sejarah

\begin{tabular}{lccc}
\hline & Skor min & Sisihan piawai & Tahap \\
\hline Kemahiran Pemikiran Sejarah & 3.38 & 0.71 & Sederhana \\
(a) Memahami kronologi & 3.55 & 0.82 & Sederhana \\
(b) Meneroka Bukti & 3.39 & 0.95 & Sederhana \\
(c) Membuat Interpretasi & 3.33 & 0.83 & Sederhana \\
(d) Membuat Imaginasi & 3.38 & 0.73 & Sederhana \\
(e) Membuat Rasionalisasi & 3.26 & 0.74 & Sederhana \\
\hline
\end{tabular}

Tahap pengamalan kemahiran pemikiran sejarah melalui penggunaan sumber digital sejarah dalam pendekatan Flipped Classroom bagi murid lelaki dan perempuan

Berdasarkan Jadual 3, min pengamalan kemahiran pemikiran sejarah bagi murid perempuan adalah lebih tinggi $(M=3.53, S D=0.71)$ berbanding dengan murid lelaki $(M=3.18, S D=0.68)$ dan tahap 
pengamalan kemahiran pemikiran sejarah bagi murid lelaki dan murid perempuan adalah berada pada tahap sederhana dalam kajian ini. Dari segi konstruknya pula, min pengamalan kemahiran memahami kronologi adalah lebih tinggi bagi murid perempuan $(M=3.68, S D=0.87)$ dan berada pada tahap tinggi berbanding dengan murid lelaki $(M=3.36, S D=0.73)$ yang berada pada tahap sederhana. Selain itu, min pengamalan kemahiran memahami kronologi bagi murid perempuan adalah lebih tinggi $(M=3.50$, $S D=0.96)$ berbanding dengan murid lelaki $(M=3.23, S D=0.93)$ dan tahap pengamalan kemahiran meneroka bukti bagi murid lelaki dan murid perempuan adalah berada pada tahap sederhana. Seterusnya, min pengamalan kemahiran membuat interpretasi adalah lebih tinggi bagi murid perempuan $(M=3.00, S D=0.85)$ berbanding dengan murid lelaki $(M=3.56, S D=0.76)$ dan tahap pengamalan kemahiran membuat interpretasi bagi murid lelaki dan murid perempuan adalah berada pada tahap sederhana. Tambahan pula, min pengamalan kemahiran membuat imaginasi adalah lebih tinggi bagi murid perempuan $(M=3.54, S D=0.78)$ berbanding dengan murid lelaki $(M=3.15, S D=0.59)$ dan tahap pengamalan kemahiran membuat imaginasi adalah berada pada tahap sederhana. Akhir sekali, min pengamalan kemahiran membuat rasionalisasi adalah lebih tinggi $(M=3.35, S D=0.65)$ berbanding dengan murid lelaki $(M=3.13, S D=0.88)$ dan tahap pengamalan kemahiran membuat rasionalisasi bagi murid lelaki dan murid perempuan adalah berada pada tahap seerhana. Justeru, dapat dirumuskan bahawa tahap pengamalan kemahiran pemikiran sejarah dan kelima-lima konstruknya berada pada tahap sederhana bagi murid lelaki dan murid perempuan kecuali bagi konstruk kemahiran memahami kronologi bagi murid perempuan yang berada pada tahap yang tinggi melalui penggunaan sumber digital sejarah dalam pendekatan Flipped Classroom dalam kajian ini.

Jadual 3: Skor Min Pengamalan Kemahiran Pemikiran Sejarah

\begin{tabular}{|c|c|c|c|c|c|c|}
\hline & \multicolumn{3}{|c|}{ Murid Lelaki (N=13) } & \multicolumn{3}{|c|}{ Murid Perempuan (N=19) } \\
\hline & $\begin{array}{c}\text { Skor } \\
\text { min }\end{array}$ & $\begin{array}{c}\text { Sisihan } \\
\text { piawai }\end{array}$ & Tahap & $\begin{array}{c}\text { Skor } \\
\text { min }\end{array}$ & $\begin{array}{c}\text { Sisihan } \\
\text { piawai }\end{array}$ & Tahap \\
\hline $\begin{array}{ll}\text { Kemahiran } & \text { Pemikiran } \\
\text { Sejarah } & \end{array}$ & 3.18 & 0.68 & Sederhana & 3.53 & 0.71 & Sederhana \\
\hline (a) Memahami kronologi & 3.36 & 0.73 & Sederhana & 3.68 & 0.87 & Tinggi \\
\hline (b) Meneroka Bukti & 3.23 & 0.93 & Sederhana & 3.50 & 0.96 & Sederhana \\
\hline (c) Membuat Interpretasi & 3.00 & 0.85 & Sederhana & 3.56 & 0.76 & Sederhana \\
\hline (d) Membuat Imaginasi & 3.15 & 0.59 & Sederhana & 3.54 & 0.78 & Sederhana \\
\hline (e) Membuat Rasionalisasi & 3.13 & 0.88 & Sederhana & 3.35 & 0.65 & Sederhana \\
\hline
\end{tabular}

\section{Perbezaan min pengamalan kemahiran pemikiran sejarah}

\section{$H_{o 1}:$ Tidak terdapat perbezaan yang signifikan bagi min pengamalan kemahiran pemikiran sejarah melalui penggunaan sumber digital sejarah dalam pendekatan Flipped Classroom berdasarkan jantina.}

Berdasarkan keputusan ujian Levene's yang tidak signifikan $[F=0.43, p=0.52]$ pada Jadual 4 telah menunjukkan bahawa tidak terdapat perbezaan yang signifikan bagi min pengamalan kemahiran pemikiran sejarah $[t(30)=-1.40, p=0.19]$ berdasarkan jantina. Maka, hipotesis nol $\left(\mathrm{H}_{\mathrm{ol}}\right)$ telah gagal ditolak. Justeru, dapat dirumuskan bahawa jantina tidak mempengaruhi pengamalan kemahiran pemikiran sejarah melalui penggunaan sumber digital sejarah dalam pendekatan Flipped Classroom dalam kajian ini dalam kajian ini.

Jadual 4: Ujian-t Sampel Tak Bersandar Bagi Pengamalan Kemahiran Pemikiran Sejarah

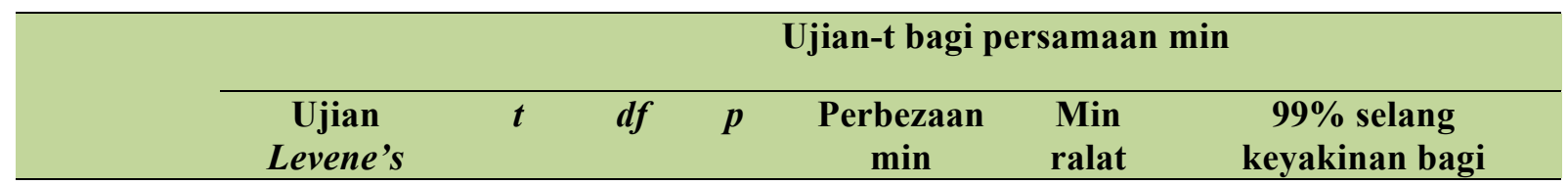


DOI: https://doi.org/10.47405/mjssh.v5i5.419

\begin{tabular}{|c|c|c|c|c|c|c|c|c|c|}
\hline & & & & & & & \multirow[t]{2}{*}{ Piawai } & \multicolumn{2}{|c|}{ perbezaan } \\
\hline & $F$ & Sig & & & & & & Bawah & Atas \\
\hline $\begin{array}{l}\text { Perbezaan } \\
\text { Min }\end{array}$ & 0.43 & 0.52 & -1.40 & 30 & 0.19 & -0.35 & 0.25 & -0.87 & 0.16 \\
\hline
\end{tabular}

$H_{o 2:}$ Tidak terdapat perbezaan yang signifikan bagi min pengamalan kemahiran memahami kronologi, kemahiran meneroka bukti, kemahiran membuat interpretasi, kemahiran membuat imaginasi dan kemahiran membuat rasionalisasi melalui penggunaan sumber digital sejarah dalam pendekatan Flipped Classroom berdasarkan jantina

Berdasarkan keputusan ujian Box's $M$ yang menunjukkan keputusan tidak signifikan, ujian multivariate pada Jadual 5 telah melaporkan nilai Pillai's Trace $[F(3,26)=1.06, p=0.41]$ yang menunjukkan bahawa tidak terdapat kesan jantina yang signifikan bagi pengamalan kemahiran memahami kronologi, kemahiran meneroka bukti, kemahiran membuat interpretasi, kemahiran membuat imaginasi dan kemahiran membuat rasionalisasi. Seterusnya, walaupun nilai ujian Levene's bagi pengamalan kemahiran memahami kronologi, kemahiran meneroka bukti, kemahiran membuat interpretasi, kemahiran membuat imaginasi dan kemahiran membuat rasionalisasi adalah tidak signifikan dan mematuhi syarat pengujian ujian multivariate, namun ujian kesan antara subjek pada Jadual 6 menunjukkan bahawa pengamalan kemahiran memahami kronologi $[F(1,30)=1.13, p=0.30]$, kemahiran meneroka bukti $[F(1,30)=0.63, p=0.43]$, kemahiran membuat interpretasi $[F(1,30)=3.90$, $p=0.06]$, kemahiran membuat imaginasi $[F(1,30)=2.30, p=0.14]$ dan kemahiran membuat rasionalisasi $[F(1,30)=0.68, p=0.42]$ berdasarkan jantina adalah tidak signifikan. Maka, hipotesis nol $\left(\mathrm{Ho}_{2}\right)$ telah gagal ditolak. Justeru, dapat dirumuskan bahawa jantina tidak mempengaruhi tahap pengamalan kemahiran memahami kronologi, kemahiran meneroka bukti, kemahiran membuat interpretasi, kemahiran membuat imaginasi dan kemahiran membuat rasionalisasi melalui penggunaan sumber digital sejarah dalam pendekatan Flipped Classroom dalam kajian ini.

Jadual 5: Ujian Multivariate

\begin{tabular}{|c|c|c|c|c|c|c|c|}
\hline Kesan & & Nilai & $F$ & $\begin{array}{c}\text { Hipotesis } \\
\quad d f\end{array}$ & $\begin{array}{c}\text { Ralat } \\
d f\end{array}$ & Sig. & $\begin{array}{c}\text { Separa } \\
\text { Eta } \\
\text { Kuasa } \\
\text { Dua }\end{array}$ \\
\hline \multirow[t]{4}{*}{ Pintasan } & Pillai's Trace & 0.96 & 129.21 & 5.00 & 26.00 & 0.00 & 0.96 \\
\hline & Wilks' Lambda & 0.04 & 129.21 & 5.00 & 26.00 & 0.00 & 0.96 \\
\hline & Hotelling's Trace & 24.85 & 129.21 & 5.00 & 26.00 & 0.00 & 0.96 \\
\hline & Roy's Largest Root & 24.85 & 129.21 & 5.00 & 26.00 & 0.00 & 0.96 \\
\hline \multirow[t]{4}{*}{ Jantina } & Pillai's Trace & 0.17 & 1.06 & 5.00 & 26.00 & 0.41 & 0.17 \\
\hline & Wilks' Lambda & 0.83 & 1.06 & 5.00 & 26.00 & 0.41 & 0.17 \\
\hline & Hotelling's Trace & 0.20 & 1.06 & 5.00 & 26.00 & 0.41 & 0.17 \\
\hline & Roy's Largest Root & 0.20 & 1.06 & 5.00 & 26.00 & 0.41 & 0.17 \\
\hline
\end{tabular}

Jadual 6: Ujian Kesan Antara Subjek

\begin{tabular}{|c|c|c|c|c|c|c|c|}
\hline Sumber & $\begin{array}{c}\text { Variabel } \\
\text { bersandar }\end{array}$ & $\begin{array}{c}\text { Jumlah } \\
\text { Kuasa dua } \\
\text { Jenis III }\end{array}$ & $\begin{array}{c}\text { Darjah } \\
\text { kebebasan }\end{array}$ & $\begin{array}{l}\text { Kuasa } \\
\text { Dua } \\
\text { Min }\end{array}$ & $F$ & Sig. & $\begin{array}{c}\text { Separa } \\
\text { Eta } \\
\text { Kuasa } \\
\text { Dua }\end{array}$ \\
\hline Model yang & Kronologi & 0.76 & 1 & 0.76 & 1.13 & 0.30 & 0.04 \\
\hline diperbetulkan & Bukti & 0.58 & 1 & 0.58 & 0.63 & 0.43 & 0.02 \\
\hline
\end{tabular}


Malaysian Journal of Social Sciences and Humanities (MJSSH), Volume 5, Issue 5, (page 72 - 80), 2020

DOI: https://doi.org/10.47405/mjssh.v5i5.419

\begin{tabular}{|c|c|c|c|c|c|c|c|}
\hline & Interpretasi & 2.46 & 1 & 2.46 & 3.90 & 0.06 & 0.12 \\
\hline & Imaginasi & 1.16 & 1 & 1.16 & 2.30 & 0.14 & 0.07 \\
\hline & Rasionalisasi & 0.38 & 1 & 0.38 & 0.68 & 0.42 & 0.02 \\
\hline \multirow[t]{5}{*}{ Pintasan } & Kronologi & 382.48 & 1 & 382.48 & 569.70 & 0.00 & 0.95 \\
\hline & Bukti & 350.08 & 1 & 350.08 & 384.67 & 0.00 & 0.93 \\
\hline & Interpretasi & 332.56 & 1 & 332.56 & 528.53 & 0.00 & 0.95 \\
\hline & Imaginasi & 345.99 & 1 & 345.99 & 685.39 & 0.00 & 0.96 \\
\hline & Rasionalisasi & 324.64 & 1 & 324.64 & 580.80 & 0.00 & 0.95 \\
\hline \multirow[t]{5}{*}{ Jantina } & Kronologi & 0.76 & 1 & 0.76 & 1.13 & 0.30 & 0.04 \\
\hline & Bukti & 0.58 & 1 & 0.58 & 0.63 & 0.43 & 0.02 \\
\hline & Interpretasi & 2.46 & 1 & 2.46 & 0.39 & 0.06 & 0.12 \\
\hline & Imaginasi & 1.16 & 1 & 1.16 & 2.30 & 0.14 & 0.07 \\
\hline & Rasionalisasi & 0.38 & 1 & 0.38 & 0.68 & 0.42 & 0.02 \\
\hline \multirow[t]{5}{*}{ Ralat } & Kronologi & 20.14 & 30 & 0.67 & & & \\
\hline & Bukti & 27.30 & 30 & 0.91 & & & \\
\hline & Interpretasi & 18.88 & 30 & 0.63 & & & \\
\hline & Imaginasi & 15.15 & 30 & 0.51 & & & \\
\hline & Rasionalisasi & 16.77 & 30 & 0.56 & & & \\
\hline \multirow[t]{5}{*}{ Jumlah } & Kronologi & 423.98 & 32 & & & & \\
\hline & Bukti & 396.25 & 32 & & & & \\
\hline & Interpretasi & 372.20 & 32 & & & & \\
\hline & Imaginasi & 382.74 & 32 & & & & \\
\hline & Rasionalisasi & 357.94 & 32 & & & & \\
\hline Jumlah yang & Kronologi & 20.90 & 31 & & & & \\
\hline \multirow[t]{4}{*}{ Diperbetulkan } & Bukti & 27.88 & 31 & & & & \\
\hline & Interpretasi & 21.33 & 31 & & & & \\
\hline & Imaginasi & 16.30 & 31 & & & & \\
\hline & Rasionalisasi & 17.15 & 31 & & & & \\
\hline
\end{tabular}

$\stackrel{\text { a }}{.}$ R Squard $=0.36$ (Adjusted R Squared $=0.00$ )

b. R Squard $=0.21$ (Adjusted R Squared $=-0.01$ )

c. R Squard $=0.12$ (Adjusted R Squared $=0.09$ )

d. R Squard $=0.07$ (Adjusted R Squared $=0.04$ )

'. R Squard $=0.02$ (Adjusted R Squared $=-0.01$ )

\section{Perbincangan Kajian}

Kajian ini menunjukkan bahawa tahap pengamalan kemahiran pemikiran sejarah melalui penggunaan sumber digital sejarah dalam pendekatan Flipped Classroom adalah sederhana secara keseluruhannya dalam kalangan murid. Tambahan pula, tahap pengamalan bagi kelima-lima konstruk dalam kemahiran pemikiran sejarah iaitu kemahiran memahami kronologi, kemahiran meneroka bukti, kemahiran membuat interpretasi, kemahiran membuat imaginasi dan kemahiran membuat rasionalisasi juga berada pada tahap sederhana dalam kajian ini. Sungguhpun tahap pengamalan kemahiran pemikiran sejarah dan kelima-lima konstruknya berada pada tahap sederhana dalam kajian, namun dapatan kajian ini telah membuktikan bahawa murid tingkatan satu juga dapat meneroka pelbagai sumber digital sejarah melalui pendekatan Flipped Classroom dalam proses pembelajaran sejarah, di samping dapat membanding beza antara maklumat dan fakta sejarah yang diperolehi (Westermann, 2014; Wineburg, 1991; Reisman, 2012; Aidinopoulou \& Sampson, 2017; Renuka Ramakrishnan, Norizan Esa \& Siti Hawa Abdullah, 2014). Tambahan pula, melalui pendekatan Flipped Classroom yang dilaksanakan telah membolehkan murid-murid terlibat dengan aktif dalam proses pengkajian sejarah dan proses pembinaan pemikiran aras tinggi dimana murid-murid dapat membaca bahan atau sumber di luar kelas dan mengkajinya secara mendalam semasa di dalam kelas (Bergamann \& Sams, 2012; Overmyer, 2012; Fulton, 201). Tambahan pula, dapatan kajian ini yang menunjukkan tahap pengamalan kemahiran pemikiran sejarah dan konstruknya yang lebih baik bagi murid perempuan berbanding dengan murid lelaki adalah konsisten dengan dapatan kajian Norul Haida Reduzan (2012) yang melaporkan bahawa murid perempuan menunjukkan tahap pencapaian bahasa melayu yang lebih baik 
melalui pembelajaran secara koperatif, kajian Zamri Mahamod dan Noor Syazwani Roni (2013) yang melaporkan bahawa tahap kemahiran generik dalam kesusasteraan melayu yang lebih tinggi bagi murid perempuan berbanding dengan murid lelaki dan kajian Zurida Haji Ismail, Mohd Ali Samsudin dan Ahmad Nurulazaman Mohd Zain (2005) yang melaporkan bahawa tahap pencapaian fizik bagi murid perempuan adalah lebih tinggi berbanding dengan murid lelaki melalui kaedah pengajaran kontekstual yang telah menyokong dapatan kajian ini secara tidak langsung. Justeru, dapat dirumuskan bahawa jantina adalah didapati tidak mempengaruhi pengamalan kemahiran pemikiran sejarah, malah perancangan dan pelaksanaan suatu kaedah pengajaran secara teratur adalah berkesan untuk membentuk proses pembelajaran yang bermakna.

\section{Kesimpulan}

Kajian ini menunjukkan bahawa tahap pengamalan kemahiran pemikiran sejarah dalam kalangan murid melalui penggunaan sumber digital sejarah dalam pendekatan Flipped Classroom adalah sederhana. Dapatan kajian ini telah membuktikan bahawa murid-murid boleh berfikir secara kritis dan kreatif terhadap sesuatu peristiwa sejarah dengan lebih mendalam dalam era perkembangan teknologi maklumat yang semakin pesat seperti yang disarankan dalam Pelan Pembangunan Pendidikan 20132025 (KPM, 2013).

\section{Rujukan}

Aidinopoulou, V., \& Sampson, D. (2017). An Action Research Study From Implementing the Flipped Classroom Model in Primary School History Teaching and Learning. Educational Technology \& Society, 20(1), 237-247.

Aktin, K. (2016). A Semiotic analysis on the Ultization of Historical Thinking Skills in Pre-School Period. Academic Journals, 11, 1335-1366.

Barton, K.C. (2018). Historical Sources in the classroom. Purpose and use. HSSE Online, 7(2), 1-11.

Bergamann, J., \& Sams, A. (2012). Flip Your Classroom. Reach Every Student in Every Class Every Day. Eugene: International Society of Technology in Education.

Cowgill II, D.A., \& Waring, S.M. (2017). Historical Thinking: An Evaluation of Students and Teacher Ability to Analyze Sources. Journal of Social Studies Education Research, 8(1), 115-145.

Fulton, K. (2012). Upside down and inside out: Flip your classroom to improve student learning. Learning \& Leading with Technology, 39(8), 12-17.

Gaughan, J.E. (2014). "The Flipped Classroom in World History". The History Teacher, 47(2), 221244.

Haydn, T., Arthur, J. \& Hunt, M. (2001). Learning to Teach History in the Secondary School: A Companion to School Experience. London: Routledge Falmer.

Hazri Jamil. (2003). Teknik Mengajar Sejarah. Kuala Lumpur: PTS.

Hendry, J. (2007). Primary sources in K-12 education: Opportunities for archives. The American Archivist, 70(1), 114-129.

Jamil Ahmad. (2002). Pemupukan Budaya Penyelidikan di Kalangan Guru di Sekolah: Satu Penilaian. Tesis Ijazah Kedoktoran, Fakulti Pendidikan: Universiti Kebangsaan Malaysia.

Kementerian Pendidikan Malaysia. (2013). Pelan Induk Pembangunan Pendidikan 2013-2025. Putrajaya: Kementerian Pendidikan Malaysia.

Lage, M.J., Platt, G.J., \& Tregilia, M. (2000). Inverting the Classroom: A Gateway to Creating an Inclusive Learning Environment. The Journal of Economic Education, 32(1), 30-43.

Leicht, R.M., Zappe, S. E., Messner, J.I., \& Litzinger, T. (2012). Employing the classroom flip to move lecture out of the classroom. Journal of Applications and Practices in Engineering Education, 3(1), 1-5.

Library of Congress. (2018). Using Primary Sources. Retrieved from https://www.loc.gov/collections/

Mohd Amin Embi \& Ebrahim Panah. (2014). Overview of Flipped Learning. Centre for Teaching \& Learning Technologies: Universiti Kebangsaan Malaysia.

Norul Haida Redzuan. (2012). Pembelajaran secara koperatif dalam kelas bahasa melayu. PENDETA: Journal of Malay, Language, Education and Literature, 3, 52-70. 
DOI: https://doi.org/10.47405/mjssh.v5i5.419

Nunnally, J.C. (1978). Psychometrie Theory $\left(2^{\text {nd }}\right.$ Ed). New York: McGraw Hill.

Overmyer, J. (2012). Flipped Classroom 101. Principal, 46-47.

Pusat Perkembangan Kurikulum. (2015). Dokumen Standard Kurikulum dan Pentaksiran Mata Pelajaran Sejarah Tingkatan Satu. Putrajaya: Kementerian Pendidikan Malaysia.

Reisman, A. (2012). The "Document-based Lesson": Bringing Disciplinary Inquiry into high School History Classroom with Adolescent struggling readers. Journal of Curriculum Studies, 44(2), 233-264.

Renuka Ramakrishnan, Norizan Esa \& Siti Hawa Abdullah. (2014). Kesan Penggunaan Sumber Sejarah Digital Terhadap Kemahiran Pemikiran Sejarah. 23 ${ }^{\text {rd }}$ International Conference of Historians of Asia 2014 (IAHA 2014), 23-27 Ogos 2014, Alor Setar, Kedah Malaysia.

Rosy Talin, (2015). Historical Thinking Skills - The Forgotten Skills?. International Journal of Learning and Teaching, 7(1), 15-23.

Rozinah Jamaludin \& Siti Zuraidah Md Isman. (2014). The use of a flipped classroom to enhance engagement and promote active learning. Journal of Education and Practice, 5(2), 124-131.

Strayer, J.F. (2012). How learning in an inverted classroom influence cooperation, innovation and task orientation. Learning Environment Reseach, 15, 171-193.

Tucker, B. (2012). The flipped classroom: Online instruction at home free class time for learning. Education Next Winter 12(1). Retrieved from: http://educationnext.org/the-flipped-classroom/

Westermann, E.D. (2014). "A Half-Flipped Classroom or An Alternative Approach? Primary Sources and Blended Learning". Journal Educational Research Quarterly, 38(2).

Wilson, S.G. (2013). The flipped class: A method to address the challenges of an undergraduate statistics cource. Teaching of Psychology, 40(3), 193-199.

Wineburg, S. (1991). On the Reading of Historical Texts: Notes on the Breach between School and Academy. American Educational research Journal, 28(3), 495- 519.

Zamri Mahamod \& Noor Syazwani Roni. (2013). Tahap kemahiran generik pelajar dalam pembelajaran kesusasteraan melayu. Jurnal Teknologi, 64(1), 17-23

Zurida Haji Ismail, Mohd Ali Samsudin \& Ahmad Nurulazam Mohd Zain. (2005). Kesan pengajaran konstektual ke atas pencapaian pelajar dalam fizik. Jurnal Pendidik dan Pendidikan, 20, 43-52. 